\title{
Review
}

\section{Estetrol: A New Choice for Contraception}

\author{
Franca Fruzzetti ${ }^{*}+{ }^{\dagger}$, Tiziana Fidecicchi ${ }^{+}[$, Maria Magdalena Montt Guevara $(\mathbb{C})$ and Tommaso Simoncini \\ Department of Obstetrics and Gynecology, Pisa University Hospital, 56126 Pisa, Italy; \\ t.fidecicchi@gmail.com (T.F.); magdalena.montt@gmail.com (M.M.M.G.); tommaso.simoncini@unipi.it (T.S.) \\ * Correspondence: ffruzzi15@gmail.com; Tel.: +39-050-992-801 \\ † Equally contributing authors.
}

Citation: Fruzzetti, F.; Fidecicchi, T.; Montt Guevara, M.M.; Simoncini, T. Estetrol: A New Choice for Contraception. J. Clin. Med. 2021, 10, 5625. https://doi.org/10.3390/ jcm10235625

Academic Editor: Michal Kovo

Received: 14 September 2021

Accepted: 27 November 2021

Published: 29 November 2021

Publisher's Note: MDPI stays neutral with regard to jurisdictional claims in published maps and institutional affiliations.

Copyright: (c) 2021 by the authors. Licensee MDPI, Basel, Switzerland. This article is an open access article distributed under the terms and conditions of the Creative Commons Attribution (CC BY) license (https:// creativecommons.org/licenses/by/ $4.0 /)$.

\begin{abstract}
Estetrol (E4) is a natural estrogenic steroid that is normally produced by human fetal liver. Recent research has demonstrated that it is a potent, orally bioavailable, natural selective estrogen receptor modulator; it has a moderate affinity for both human estrogen receptor alpha (ER $\alpha)$ and $E R \beta$, with a preference for ER $\alpha$. Clinical studies have demonstrated possible use as an estrogen in combined oral contraceptives (COC). COCs containing E4 and drospirenone (DRSP) showed a high acceptability, tolerability, and user satisfaction also when compared to COCs containing ethinylestradiol (EE). E4/DRSP effectively inhibits ovulation, with a similar effect on endometrium thickness than that of EE-containing COCs. Low doses (15 mg) of E4 with DRSP (3 mg) showed promising results in term of bleeding pattern and cycle control, also when compared to other COCs containing synthetic estrogens. Moreover, the association has limited effects on serum lipids, liver, SHBG levels, and carbohydrate metabolism. This combination also could drive a lower risk of venous thromboembolism than EE-containing COCs. In this review, we will summarize the actual knowledge about the new E4-containing contraceptive. Further large-scale studies in the full target population are needed to provide more insights into the cardiovascular safety profile and user satisfaction of E4/DRSP.
\end{abstract}

Keywords: combined hormonal contraception; estetrol; metabolism; SHBG; cycle control; hemostasis

\section{Introduction}

Estetrol (E4) is a human natural estrogen which was discovered in 1965 in urines of pregnant women [1,2]. It is only produced during human pregnancy and it reaches the maternal circulation through the placenta [3,4]. Human maternal plasma levels increase during pregnancy, reaching high concentrations towards the end of gestation $(\geq 1 \mathrm{ng} / \mathrm{mL})$. Fetal plasma levels have been reported to be nearly 20 times higher than maternal plasma levels at parturition [5]. After delivery, blood levels of E4 become rapidly undetectable [6,7]. It is of interest that E4 is not produced by other species tested so far (mice, rat, and rabbit). The role as a marker of fetal health have been studied for many years but no correlation was found [7,8]. Even now the physiological significance of E4 in pregnancy is unknown.

In this review we summarize the actual knowledge about E4, focusing the attention on its new application for hormonal contraception.

\section{Biosynthesis and Pharmacological Properties}

Its chemical structure is the 15-hydroxyethryol or the oestra-1,3,5(10)-trien-3,15-16,17tethrol: the molecule has 4-OH groups, so it's also called with the name E4 (Figure 1).

E4 is synthesized during pregnancy from estradiol (E2) and estriol (E3) by two fetal liver enzymes through hydroxylation. These two enzymes are $15 \alpha$ and $16 \alpha$-hydroxylase and they are expressed only during fetal age [4].

E4 is extensively metabolized or inactivated by human hepatocytes in vitro, producing metabolites by direct glucuronidation of the D-ring and direct sulfation at an unconfirmed site. E4 is mainly excreted in the urine rather than through the biliary route, and it is the 
terminal product of its own pathway: there are not secondary reactions that could produce E3, E2, or estrone (E1) $[9,10]$.

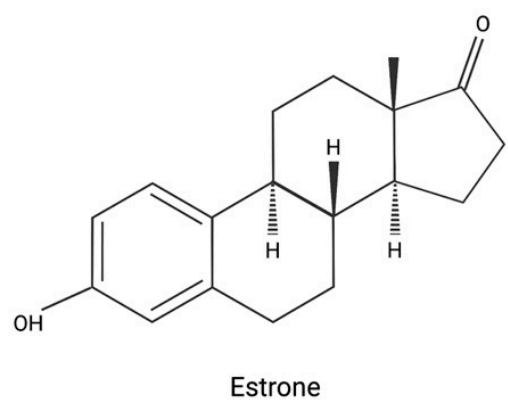

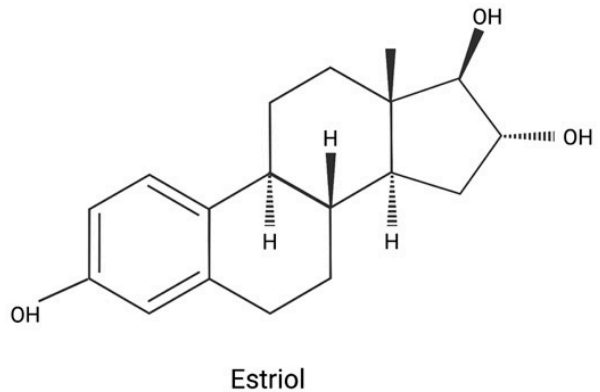

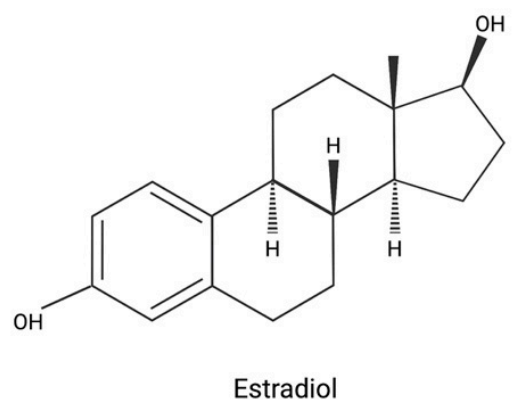<smiles>CC(C)(Cl)C(F)(F)F</smiles>

Figure 1. Molecular structure of different estrogens. Created with BioRender.com (4 September 2021).

E4 displays moderate protein binding (close to 50\%) in human plasma. E4 does not bind to human sex hormone-binding globulin (SHBG) [11]. It is equally distributed between plasma and blood cells in human blood. E4 has a high oral bioavailability (90\%) and an important long half-life in humans, with an average of 28-32 h half-life, which is about two-fold longer than E2 [9]. In contrast to E2, E4 does not show clinically relevant inhibiting or inducing interactions with cytochrome P450 liver enzymes or with other molecules [11,12].

In the 1970s and 1980s different studies demonstrated that E4 has a weaker estrogenic activity than E2, E3, and tamoxifen: this activity has been shown in uterus $[5,7,8]$. In fact, study shows that E4 has a low to moderate affinity for both human estrogen receptor $\alpha(E R \alpha)$ and $\beta(E R \beta)$ with a 4/5-fold preference for $E R \alpha[10]$. Based on this relatively low receptor binding affinity compared to E2, E4 was originally thought to be a weak estrogen [12,13].

Recent studies indicate that E4 is an estrogen with a distinctive profile of ER $\alpha$ activation. E4 activates the nuclear ER $\alpha$, but it is an antagonist of the membrane ER $\alpha$, in contrast to other estrogens [14-16]. Based on its pharmacological profile, E4 can be classified as the first Natural Estrogen with Selective Action in Tissues (NEST) [17]. NEST activities of E4 are the consequence of its unique dual role.

\section{Effects on Different Tissues}

E4 may display different effects on different tissues due to its agonist or antagonist activity on ERs.

In well validated and predictive rat models, E4 behaves as an estrogen agonist in all tissues investigated, i.e., bone, vagina, myometrium, endometrium, and brain, and it is effective in inhibiting ovulation by reducing follicle stimulating hormone (FSH) and luteinizing hormone (LH) plasma concentrations $[8,18,19]$. A study reported a beneficial effect of E4 on bone, through the analysis of different markers like: bone mineral density (BMD), mineralization of vertebral bodies from L3 to L5, strength against biomechanical damages and level of serum osteocalcin [18]. Another set of study was done on CNS, suggesting a neuroprotective role of E4 $[19,20]$. It was observed that in ovariectomized 
rats treated with $\mathrm{E} 4$ the expression of allopregnanolone and $\beta$-endorphin in serum was increased and different cerebral areas like frontal cortex, hippocampus, and pituitary gland were induced. The expression of those neurosteroids are reduced when E4 and E2 are given together $[19,20]$.

Most beneficial effects of E4 on the vascular system have been ascribed to the activation of the membrane ER $\alpha$ of vascular endothelial cells, including enhancement of nitric oxide (NO) production, vasodilation, and prevention of atherosclerosis, of neointimal proliferation, and of hypertension [8].

On breast tumor tissue it acts as an estrogen antagonist in the presence of E2 [21,22]. The estrogen-antagonistic effect of $\mathrm{E} 4$ in the breast has been further supported by a recent pre-clinical study that has been performed in women with breast cancer, finding that E4 reduces breast cancer cells proliferation [21,23-26]. These features could suggest a future role of E4 as a selective estrogen receptor modulator (SERM), but with less adverse effect than tamoxifen (hot flushes, nausea, hypertension, thromboembolic events, endometrial hyperplasia) $[24,27,28]$. However, in 2008 a study showed that $\mathrm{E} 4$ has a weak proliferative activity on mammary tumoral MCF-7 cells [27] and surprisingly it acts as an estrogen antagonist on rat breast DMBA model cells, where it prevents the development of new breast tumors and stimulates the regression of pre-existing ones [28,29].

Some of the principal physiological role and properties of $\mathrm{E} 4$ on different tissues like bone, uterus, vagina, breast, CNS, and ovaries are shown in Table 1.

Table 1. Effects of estetrol on the estrogen receptor $\alpha(E R \alpha)$ and $\beta(E R \beta)$ on different tissues: brain, bone, female genital system, and breast.

Low affinity for estrogen receptors [12,13]
Higher affinity for ER $\alpha$ than ER $\beta$ [10]
A natural SERM [24,27,28]

These features are very important because they mean that $\mathrm{E} 4$ could be a useful and safe molecule in hormonal therapy. In this field, an important application of E4 is for 
combined oral contraceptives (COCs). It holds promises for the safety and tolerability of COCs containing E4.

\section{New Combined Hormonal Contraception with Estetrol}

COCs traditionally contain an estrogen and a progestin component. Estrogens are useful to stabilize the endometrium, to regulate menstrual bleeding and to reduce follicle development. The most used estrogen is ethinylestradiol (EE), variously combined with different progestins, but it has an impact on liver function and endothelium that can produce rare cases of venous or arterial thrombotic complications. Since 2009 COCs containing E2 has been developed to reduce this effect. E4 may represent another valid option for COCs, with many advantages linked to its dual effect on receptors.

\subsection{Ovulation and Cycle Control: How to Reach the Best Patients' Satisfaction}

The ovulation inhibitory potency of E4 was first studied in preclinical models, followed by clinical trials in women (Table 2).

Coelingh Bennink et al. in 2008 [30] studied the effectiveness of E4 as an ovulation inhibitor in regularly cycling rats compared to EE. Rats were treated orally twice daily for four consecutive days with E4 $(0.03,0.1,0.3,1.0$, or $3.0 \mathrm{mg} / \mathrm{kg})$, EE $(0.0003,0.001,0.003$, 0.01 , or $0.03 \mathrm{mg} / \mathrm{kg}$ ) or vehicle control. Ovulation was significantly inhibited with a dose of $0.3 \mathrm{mg} / \mathrm{kg}$ of E4 twice daily and above and with $0.03 \mathrm{mg} / \mathrm{kg}$ of EE twice daily. In a second experiment they also administered $2.0 \mathrm{mg} / \mathrm{kg}$ of E4 once daily or divided in two doses of $1.0 \mathrm{mg} / \mathrm{kg}$ : this second option was able to inhibit ovulation in all treated rats, while the single-dose administration acted in half of them. EE resulted to be 18 times more potent than E4 [30].

The ability to suppress LH and FSH production in female humans was studied in early post-menopause women. E4 showed a profound central inhibitory and dose dependent effect on LH and FSH in post-menopause women [33]. After a single-dose administration, a clear dose-dependent inhibition of LH levels and a profound inhibition of FSH levels over $48 \mathrm{~h}$ after $100 \mathrm{mg}$ of E4 (lasting over 7 days) was observed [9].

A phase II dose-finding pilot study evaluated the efficacy of different dosages of E4 combined with levonorgestrel (LNG) or drospirenone (DRSP) in suppressing the pituitaryovarian axis and ovulation in healthy premenopausal women [31]. E4 combined with DRSP (5 or $10 \mathrm{mg}$ E4 + $3 \mathrm{mg}$ DRSP) or LNG (5, 10 or $20 \mathrm{mg}$ E4 + $0.15 \mathrm{mg} \mathrm{LNG}$ ) in a 24/4-day regimen was compared to EE $20 \mathrm{mcg}+3 \mathrm{mg}$ DRSP, all of them administered for three consecutive cycles. The highest suppression of ovarian activity was observed in the $20 \mathrm{mg}$ E4/LNG group and was very similar to that observed with EE/DRSP. However, there were no ovulations during the treatment cycles in all treatment groups, showing the efficacy of all the combinations of E4. Endometrial thickness was also reduced similarly during treatment in all treatment groups.

The first post-treatment ovulation occurred approximately 17 days after the last treatment day in the E4/DRSP groups, and 21 days after the last active treatment in the E4/LNG and EE/DRSP groups: this period was comparable to the duration of a normal follicular phase, confirming adequate ovarian suppression during treatment. In conclusion, a dosage above $10 \mathrm{mg}$ /day of E4 with DRSP or LNG demonstrated to be a promising combination for contraception [31]. 


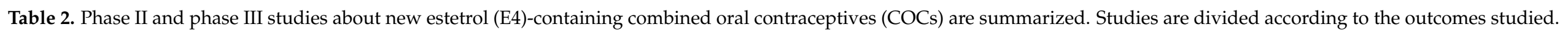

\begin{tabular}{|c|c|c|c|c|}
\hline Outcomes. & Study & E4 Combinations Tested & Comparators & Results \\
\hline \multirow{4}{*}{$\begin{array}{l}\text { Ovulation } \\
\text { inhibition and } \\
\text { cycle control }\end{array}$} & $\begin{array}{c}\text { Phase II } \\
\text { Duijkers et al., } 2015 \text { [31] }\end{array}$ & $\begin{array}{c}5 \text { or } 10 \mathrm{mg} \mathrm{E} 4+3 \mathrm{mg} \text { DRSP } \\
5,10, \text { or } 20 \mathrm{mg} \text { E } 4+0.15 \mathrm{mg} \text { LNG } \\
24+4 \text { regimen }\end{array}$ & $\begin{array}{l}0.02 \mathrm{mg} \text { EE }+3 \mathrm{mg} \text { DRSP } \\
24+4 \text { regimen }\end{array}$ & $\begin{array}{l}\text { No ovulation in any treatment group. } \\
\text { Ovarian activity inhibition proportional to E4 dosage } \\
\text { (20 mg E4/LNG like EE/DRSP) } \\
\text { Endometrial thickness similarly suppressed in all groups } \\
\text { Post-treatment ovulation occurred in all patients in the first } \\
\text { month. }\end{array}$ \\
\hline & $\begin{array}{c}\text { Phase II } \\
\text { Apter et al., } 2016 \text { [32] }\end{array}$ & $\begin{array}{c}15 \text { or } 20 \mathrm{mg} \mathrm{E} 4+3 \mathrm{mg} \text { DRSP } \\
15 \text { or } 20 \mathrm{mg} \mathrm{E} 4+0.15 \mathrm{mg} \text { LNG } \\
24+4 \text { regimen }\end{array}$ & $\begin{array}{l}\text { 4-phasic commercial packaging } \\
\text { of E2V/DNG } \\
26+2 \text { regimen }\end{array}$ & $\begin{array}{l}\text { Lowest frequency of unscheduled bleeding and/or spotting and } \\
\text { absence of withdrawal bleeding in the } 15 \mathrm{mg} \text { E4/DRSP group }\end{array}$ \\
\hline & $\begin{array}{l}\text { Phase III } \\
\text { Gemzell-Danielsson et al., } \\
2021[34]\end{array}$ & $\begin{array}{l}15 \mathrm{mg} \text { E } 4+3 \text { mg DRSP } \\
24+4 \text { regimen }\end{array}$ & / & $\begin{array}{l}\text { Method-failure PI: } 0.29 \text { pregnancies } / 100 \text { woman-years } \\
\text { Scheduled bleeding occurred in } 91.9-94.4 \% \text { of women per cycle } \\
\text { Unscheduled bleeding/spotting episodes decreased in the first } \\
6 \text { cycles and remained stable thereafter }(<16 \%)\end{array}$ \\
\hline & $\begin{array}{c}\text { Phase III } \\
\text { Creinin et al., } 2021 \text { [35] }\end{array}$ & $\begin{array}{l}15 \mathrm{mg} \text { E } 4+3 \text { mg DRSP } \\
24+4 \text { regimen }\end{array}$ & / & $\begin{array}{c}\text { Method-failure PI in } 16-35 \text { years old women: } \\
1.43 \text { pregnancies } / 100 \text { woman-years } \\
\text { Scheduled bleeding occurred in } 82.9 \text { to } 87.0 \% \text { of women per cycle } \\
\text { Unscheduled bleeding decreased in the first } 4 \text { cycles and } \\
\text { remained stable thereafter }(15.5 \% \text { to } 19.2 \%)\end{array}$ \\
\hline $\begin{array}{l}\text { Treatment } \\
\text { satisfaction }\end{array}$ & $\begin{array}{c}\text { Phase II } \\
\text { Apter et al., } 2017 \text { [36] }\end{array}$ & $\begin{array}{l}15 \text { or } 20 \mathrm{mg} \mathrm{E} 4+3 \mathrm{mg} \text { DRSP } \\
15 \text { or } 20 \mathrm{mg} \text { E } 4+0.15 \mathrm{mg} \text { LNG } \\
24+4 \text { regimen }\end{array}$ & $\begin{array}{l}4 \text {-phasic commercial packaging } \\
\text { of E2V/DNG } \\
26+2 \text { regimen }\end{array}$ & $\begin{array}{c}\text { The largest proportion of treatment satisfaction in the } 15 \mathrm{mg} \\
\text { E4/DRSP group; the lowest in the } 15 \mathrm{mg} / \mathrm{LNG} \text { group } \\
\text { Well-being with E4/DRSP: better than with E4/LNG } \\
\text { Proportion of women with a } 2 \mathrm{~kg} \text { or more weight loss: the highest } \\
\text { with } 15 \mathrm{mg} \text { E4/DRSP }\end{array}$ \\
\hline \multirow{2}{*}{ Hemostatic effect } & $\begin{array}{c}\text { Phase II } \\
\text { Kluft et al., } 2017 \text { [37] }\end{array}$ & $\begin{array}{l}5 \text { or } 10 \mathrm{mg} \text { E } 4+3 \mathrm{mg} \text { DRSP } \\
24+4 \text { regimen }\end{array}$ & $\begin{array}{l}0.02 \mathrm{mg} \text { EE }+3 \mathrm{mg} \text { DRSP } \\
24+4 \text { regimen }\end{array}$ & $\begin{array}{l}\text { E4/DRSP no or minor effect on markers of coagulation inhibition; } \\
\text { they were reduced by EE/DRSP thus promoting coagulation } \\
\text { E4/DRSP did not increase D-dimer levels, unlike EE/DRSP }\end{array}$ \\
\hline & $\begin{array}{c}\text { Phase II } \\
\text { Douxfils et al., } 2020[38]\end{array}$ & $\begin{array}{l}15 \mathrm{mg} \text { E } 4+3 \text { mg DRSP } \\
24+4 \text { regimen }\end{array}$ & $\begin{array}{l}0.02 \mathrm{mg} \text { EE }+3 \mathrm{mg} \text { DRSP } \\
24+4 \text { regimen } \\
0.03 \mathrm{mg} \mathrm{EE}+0.15 \mathrm{mg} \text { LNG } \\
21+7 \text { regimen }\end{array}$ & $\begin{array}{c}\text { Changes in hemostasis parameters after treatment with } 6 \text { cycles of } \\
\text { E4/DRSP were smaller or like those observed for EE/LNG } \\
\text { Similar, but more pronounced changes were also observed versus } \\
\text { EE/DRSP }\end{array}$ \\
\hline
\end{tabular}


Table 2. Cont.

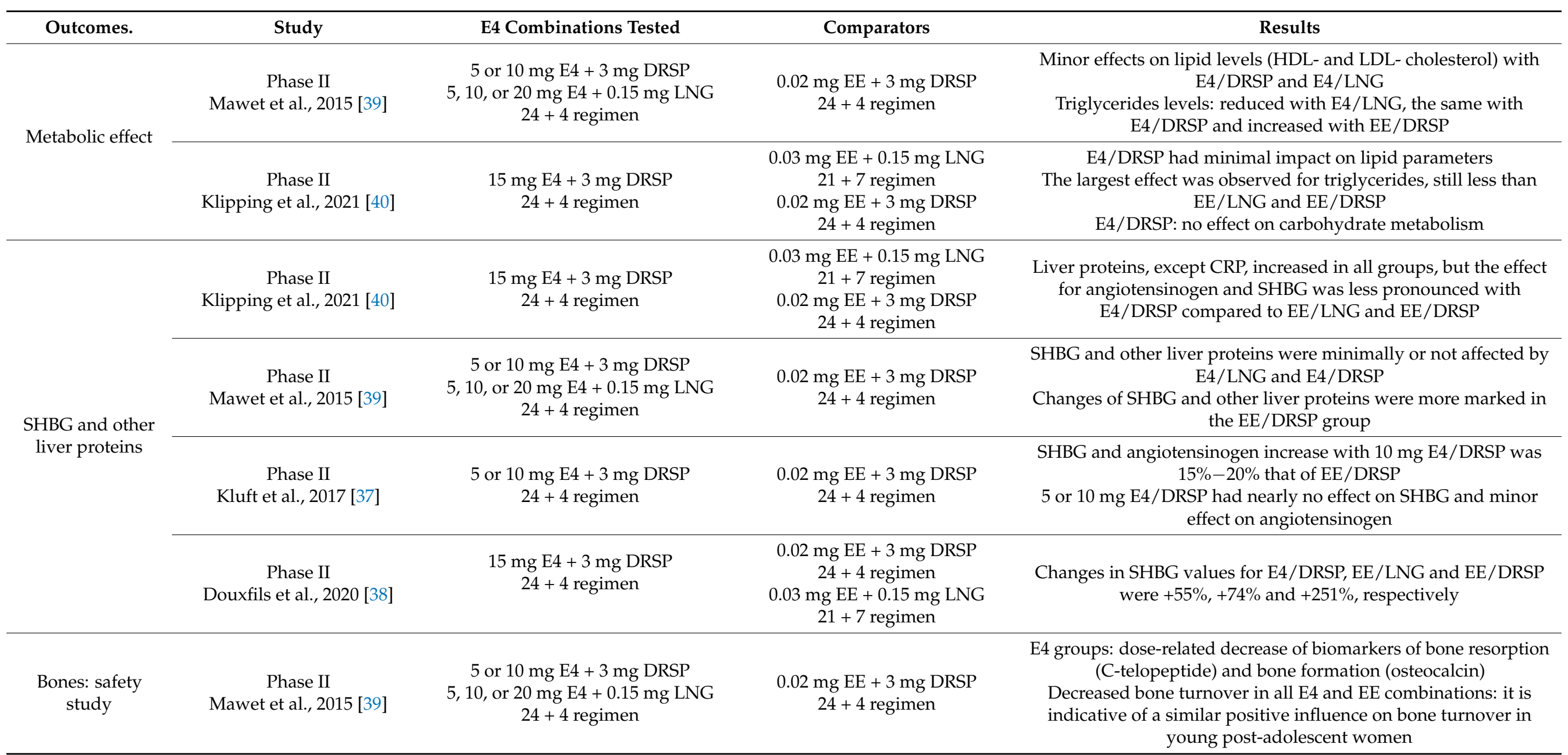

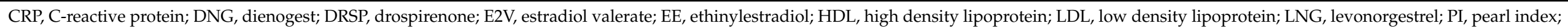
SHBG, sex hormone binding globulin. 
Another phase II study aimed to assess bleeding patterns and cycle control of E4 containing COCs in a 24/4-day regimen, using a COC containing estradiol valerate (E2V) and dienogest (DNG) as a reference [32]. E4 15 and $20 \mathrm{mg} / \mathrm{DRSP} 3 \mathrm{mg}$, E4 $20 \mathrm{mg} / \mathrm{LNG}$ $0.15 \mathrm{mg}$ and E2V/DNG were compared after six treatment cycles. The frequency of unscheduled bleeding/spotting was lower in the E4/DRSP groups compared to the other treatment groups: by cycle 6 , the frequency varied between $33.8 \%$ in the group using $15 \mathrm{mg}$ of E4 + DRSP and $47.8 \%$ in the E2V/DNG group, with increasing intensity of unscheduled bleeding over time in the E2V/DNG group. For E4/DRSP, the frequency of absence of withdrawal bleeding was 3.5 (15 mg E4) to 3.8\% (20 mg E4) at cycle 6 . In the E4/LNG groups, the frequencies were $14.0-18.5 \%$, and for E2V/DNG it was $27.1 \%$. Only $8.9 \%$ of subjects in the group using $15 \mathrm{mg}$ of E4 + DRSP discontinued prematurely. In conclusion, the $15 \mathrm{mg}$ E4/DRSP combination has been shown to be the most efficacious in terms of bleeding pattern and cycle control, compared with the other combinations investigated [32]. The largest proportion of treatment satisfaction was reported for $15 \mathrm{mg}$ E4/DRSP (73.1\%) compared to $20 \mathrm{mg}$ E4/DRSP and 15 or $20 \mathrm{mg}$ E4/LNG. Well-being with E4/DRSP combinations was statistically significantly better than with E4/LNG combinations and the administration of $15 \mathrm{mg}$ E4/DRSP favors a good weight control, with $36.7 \%$ of women losing $2 \mathrm{~kg}$ or more after 6 months of treatment [36].

After these dose-finding studies, phase III clinical trials using the combination E4 $15 \mathrm{mg}$ /DRSP $3 \mathrm{mg}$ were performed. Two studies are available by now, for a total of around 3400 women enrolled and followed for a period of 13 cycles. In the first study conducted in 1864 women aged 16 to 50 years old from North America, the PI was 2.65 in women aged 16 to 35 (54\% of the undesired pregnancies due to method failure, with a methodfailure PI of 1.43) [35]. In the second study, conducted in 1553 women from Europe and Russia between the ages of 18 and 50 years old, less pregnancies were reported, and the Pearl Index (PI) was 0.47 in the group aged 18 to 35 and 0.41 in the whole group, with a method-failure PI of 0.25 in the whole group. This was considered a sufficiently low value for an oral contraceptive. Scheduled bleeding occurred in 91.9-94.4\% of participants per cycle. Scheduled bleeding and/or spotting days remained stable throughout the study with a median duration of 4 to 5 days. Unscheduled bleeding and/or spotting episodes after Cycle 1 occurred in 19.2\% of women in Cycle 2 and decreased to $12.8 \%$ of women in Cycle 11. Among these episodes over all cycles, $71.8 \%$ were spotting-only episodes, $22.7 \%$ were mixed bleeding/spotting and 5.4\% were bleeding-only [34]. Overall, a COC with E4 $15 \mathrm{mg}$ /DRSP $3 \mathrm{mg}$ was considered effective at preventing unwanted pregnancies with a satisfactory bleeding pattern control.

\subsection{Hemostatic effect}

Historically, EE containing COCs demonstrated their efficacy and safety, with a satisfactory bleeding pattern. However, their impact on liver function and vascular endothelium could produce rare cardiovascular thrombotic complications that could limit their use in a subgroup of women. The use of androgenic progestins and the substitution of EE with E2 can modulate and reduce this risk [41,42]. E4 represents a promising option to be used for COCs. From in vitro to in vivo studies investigated its influence on hemostatic parameters.

In an in vitro study on human umbilical vein endothelial cells, the effects of E4 on fibrinolytic system and whether it could influence the ability of endothelial cells to migrate were studied [43]. Expression of plasminogen-activator inhibitor-1 (PAI-1), urokinase-type plasminogen activator ( $\mathrm{u}-\mathrm{PA})$, and tissue plasminogen activator ( $\mathrm{t}-\mathrm{PA}$ ) proteins were all increased by $\mathrm{E} 4$ in a dose-dependent manner, although $\mathrm{E} 4$ was less effective than equimolar amounts of E2. Moreover, endothelial cell migration capacity was increased by E4 treatment. So, it was concluded that E4 could regulate the fibrinolytic protein system in endothelial cells, with potential implications for the local control of blood clotting and for vascular remodeling [43].

Mouse models were also used to test E4 impact on arterial and venous thrombosis. It increased mouse tail bleeding time, it protected from both arterial and venous thrombosis, 
and it induced a resistance against acute thromboembolism. Ex vivo flow-based adhesion studies conducted in whole blood under arterial flow conditions on a collagen matrix showed that E4 treatment also reduced platelet adhesion [15].

In human studies using the new COC containing E4, more insights about this issue were given (Table 2). Kluft et al. [37] evaluated the effects of $3 \mathrm{mg}$ DRSP in combination with 5 or $10 \mathrm{mg}$ of E4 compared to a preparation containing EE $20 \mu \mathrm{g} / \mathrm{DRSP} 3 \mathrm{mg}$. Over three months, the E4-containing preparations had a much lower impact. Both E4 combinations reduced D-dimer level with no effect on antithrombin, protein $\mathrm{S}$ activity or activated protein $\mathrm{C}$ resistance, and the $5 \mathrm{mg}$ E4/DRSP combination also decreased prothrombin fragment $1+2$. It can be stated that E4/DRSP have a considerably lower hepatic and vascular estrogenicity than EE/DRSP [37].

In addition, Douxfils et al. [38] demonstrated that after six months of treatment E4 $15 \mathrm{mg} / \mathrm{DRSP} 3 \mathrm{mg}$ caused similar or smaller changes in procoagulant, anticoagulant, and fibrinolytic parameters than EE/LNG, while the difference with EE/DRSP was more pronounced [38].

\subsection{Estetrol, Metabolism, and Cardiovascular Risk}

One of the earliest manifestations of atherosclerosis is the dysfunction of the vascular endothelium, caused by one or more "insults" to the endothelium. This leads to a decrease in release of the vasodilator, nitric oxide, and an increase in production of the vasoconstrictor, endothelin-1. Although endothelial dysfunction occurs early in the atherosclerotic process, it continues throughout the progression of the disease. A second major consequence of damage to the endothelium is the accumulation of inflammatory cells in the vascular wall, that causes the oxidation and accumulation of low-density lipoproteins (LDL). This activates a vicious cycle which leads to the atheroma [44].

Estrogens are known to have a vasculoprotective action, which has been demonstrated clearly in animal models of early atheroma: E2 has been shown to strongly prevent fatty streak deposition in monkeys, rabbits, and mice [45]. They have a general cardioprotective effect: they prevent atherosclerosis [46,47], they reduce hypertensive effects of ovariectomy [48], they reduce age- and hypertension-related arterial stiffening [49], they increase the production of nitric oxide [50], they accelerate endothelial reparation processes [51], they prevent intimal post-traumatic hyperplasia [52].

E4 demonstrated to have similar vasculoprotective action in mice thanks to its binding with ER $\alpha$, even if with less potence than E2 [53-55]. Moreover, it has positive effects on metabolic parameters. A study in post-menopausal women treated with different doses of $\mathrm{E} 4(2 \mathrm{mg}, 10 \mathrm{mg}, 20 \mathrm{mg}$, or $40 \mathrm{mg}$ ) for 28 days showed that a lowering effect on LDL was accompanied with an increase in HDL and no or minimal changes in triglycerides; all the effects were dose-dependent [56].

E4 associations with different progestins were studied to evaluate their metabolic effects, in view of the formulation of new COCs (Table 2). Mawet et al. [39] made a dosefinding study in healthy normally ovulating women aged 18-35 years. They administered six different treatments in six groups of women for three consecutive cycles in a 24/4-day regimen: $5 \mathrm{mg}$ or $10 \mathrm{mg}$ of E4 with $3 \mathrm{mg}$ of DRSP; $5 \mathrm{mg}, 10 \mathrm{mg}$, or $20 \mathrm{mg}$ E4 with $0.15 \mathrm{mg}$ LNG; $0.02 \mathrm{mg}$ EE with $3 \mathrm{mg}$ DRSP as comparator. E4-containing COCs caused minor effects on lipoproteins and triglycerides compared to the EE/DRSP group [39]. In addition Klipping et al. [40] found similar results. The combination of $15 \mathrm{mg}$ of E4 and $3 \mathrm{mg}$ of DRSP had minimal impact on lipid parameters. The largest effect was observed for triglycerides, that showed a $24 \%$ increase after treatment; however, this increase was less compared to EE/LNG (+28\%) and EE/DRSP (+65.5\%) [40].

Phase III studies will better address this issue, giving information on a large population. However, phase II results show that E4/DRSP combination is substantially neutral on lipid parameters. 


\subsection{Effects on the Synthesis of Other Liver Proteins}

E4-containing COCs have a limited effect on liver function (Table 2).

SHBG is a carrier protein produced in the liver. It binds estrogens and testosterone, and its levels may be used as a surrogate to evaluate the steroid effects on the liver. SHBG may be considered as a marker for estrogenicity of a contraceptive preparation and possibly for the risk of venous thrombosis $[57,58]$. In general, estrogens can cause a dose-related increase of SHBG levels, while progestogens induce a decrease of SHBG levels, depending on the type and the dose of the progestogen used. Thus, the combination of the estrogenic effect of the estrogen contained in the hormonal contraceptive and of the antiestrogenic effect of the progestogen used (effect that is higher with androgenic progestins) determines the total estrogenicity of that hormonal contraceptive.

SHBG plasma levels decreased with E4 $(5,10$, or $20 \mathrm{mg}) / \mathrm{LNG}$, while showed a dose-dependent slight increase with 5 or $10 \mathrm{mg}$ E4/DRSP (+7.9-44.5\%). This increase is considerably less than with EE/DRSP [39]. In addition Klipping et al. [40] found a similar variation of SHBG: E4 $15 \mathrm{mg} /$ DRSP $3 \mathrm{mg}$ caused an increase of $87.15 \%$ of SHBG levels at cycle 6, still less than EE/LNG and EE/DRSP [40]. Other studies confirmed the little influence of this COC on SHBG production [37,38]. Other liver proteins were studied, too. Angiotensinogen changes showed a profile similar to SHBG [45,46,59]. C-reactive protein, cortisol binding globulin, thyroxin binding globulin, and ceruloplasmin showed slight changes with E4/DRSP $[39,40]$, confirming the limited estrogenic effect of E4 on liver also when combined to antiandrogenic progestins.

\subsection{Bones and Breast: Safety of E4-Containing COCs}

Studies about the effects of the new proposed COCs with E4 on tissues like bone and breast are still scant.

Even if some data about the preventive effect on bone loss of $\mathrm{E} 4$ alone are already available $[18,59]$, by now the only available information about effects on bone of E4-containing COCs is given by the study by Mawet et al. [39] (Table 2). A balance between bone resorption and bone formation maintains the regulation of bone mineral density. This study did not detect any imbalances after treatment with E4/DRSP, E4/LNG or the comparator EE/DRSP in serum osteocalcin (a marker of bone formation) and C-telopeptide (a marker of bone degradation). This may be indicative of a positive influence on bone turnover in young post-adolescent women, similarly to EE- or E2-containing COCs [39].

Similarly, very little is known about the effects of E4/DRSP combinations on breast. Recently, a study on breast cancer was published [60]. It shows that E4 combined with or without progesterone or DRSP promotes neither breast cancer development nor metastatic dissemination in three different models of breast cancer when used at a therapeutic dose for hormone replacement therapy or COC [60]. The results may suggest that the use of E4 in contraception could further limit the already minimal possible effect of other hormonal contraceptives on breast cancer risk. Nevertheless, at the present it is not possible to extrapolate clinical data about this issue.

\section{Conclusions}

In conclusion, pharmacological properties of E4 make it a useful molecule for hormonal therapies and contraception. By now, some phase II and phase III studies gave promising results using the combination of E4 $15 \mathrm{mg} / \mathrm{DRSP} 3 \mathrm{mg}$ : this COCs showed a good contraceptive effect and cycle control, with a neutral metabolic effect. However, still very little is known about the effects of this new combination on breast and bone. Post-marketing studies are needed to consolidate the available data and to explore all the possible side effects and risks for bone, breast, and cardiovascular system of a long-term use of E4-containing pills compared to the well-known EE- and E2-containing combinations.

Author Contributions: All authors have substantially contributed to the work. All authors have read and agreed to the published version of the manuscript. 
Funding: Authors received no external funding.

Conflicts of Interest: The authors declare no conflict of interest.

\section{References}

1. Hagen, A.; Barr, M. Metabolism of 17 $\beta$-oestradiol-4-14C in early infancy. Endocrinology 1965, 49, 207-220. [CrossRef]

2. Zucconi, G.; Lisboa, B.P.; Simonitsch, E.; Roth, L.; Hagen, A.A.; Diczfalusy, E. Isolation of 15-alpha-hydroxy-oestriol from pregnancy urine and from the urine of newborn infants. Acta Endocrinol. 1967, 56, 413-423. [CrossRef] [PubMed]

3. Schwers, J.; Eriksson, G.; Wiqvist, N.; Diczfalusy, E. $15 \alpha$-hydroxylation: A new pathway of estrogen metabolism in the human fetus and newborn. BBA-Gen. Subj. 1965, 100, 313-316. [CrossRef]

4. Schwers, J.; Eriksson, G.; Diczfalusy, E. Metabolism of oestrone and oestradiol in the human foeto-placental unit at midpregnancy. Acta Endocrinol. 1965, 49, 65-82. [CrossRef]

5. Coelingh Bennink, F.; Holinka, C.F.; Visser, M.; Coelingh Bennink, H.J.T. Maternal and fetal estetrol levels during pregnancy. Climacteric 2008, 11, 69-72. [CrossRef]

6. Tulchinsky, D.; Frigoletto, F.D.; Ryan, K.J.; Fishman, J. Plasma estetrol as an index of fetal well-being. Obstet. Gynecol. Surv. 1976, 31, 9-10. [CrossRef]

7. Kundu, N.; Wachs, M.; Iverson, G.B.; Petersen, L.P. Comparison of serum unconjugated estriol and estetrol in normal and complicated pregnancies. Obstet. Gynecol. 1981, 58, 276-281.

8. Visser, M.; Coelingh Bennink, H.J.T. Clinical applications for estetrol. J. Steroid Biochem. Mol. Biol. 2009, 114, 85-89. [CrossRef]

9. Visser, M.; Holinka, C.F.; Coelingh Bennink, H.J.T.T. First human exposure to exogenous single-dose oral estetrol in early postmenopausal women. Climacteric 2008, 11, 31-40. [CrossRef] [PubMed]

10. Visser, M.; Foidart, J.M.; Coelingh Bennink, H.J.T. In vitro effects of estetrol on receptor binding, drug targets and human liver cell metabolism. Climacteric 2008, 11, 64-68. [CrossRef] [PubMed]

11. Hammond, G.L.; Hogeveen, K.N.; Visser, M.; Coelingh Bennink, H.J.T. Estetrol does not bind sex hormone binding globulin or increase its production by human HepG2 cells. Climacteric 2008, 11, 41-46. [CrossRef]

12. Coelingh Bennink, H.J.T.; Holinka, C.F.; Diczfalusy, E. Estetrol review: Profile and potential clinical applications. Climacteric 2008, 11, 47-58. [CrossRef]

13. Holinka, C.F.; Brincat, M.; Coelingh Bennink, H.J.T. Preventive effect of oral estetrol in a menopausal hot flush model. Climacteric 2008, 11, 15-21. [CrossRef]

14. Abot, A.; Fontaine, C.; Buscato, M.; Solinhac, R.; Flouriot, G.; Fabre, A.; Drougard, A.; Rajan, S.; Laine, M.; Milon, A.; et al. The uterine and vascular actions of estetrol delineate a distinctive profile of estrogen receptor $\alpha$ modulation, uncoupling nuclear and membrane activation. EMBO Mol. Med. 2014, 6, 1328-1346. [CrossRef] [PubMed]

15. Valéra, M.C.; Noirrit-Esclassan, E.; Dupuis, M.; Fontaine, C.; Lenfant, F.; Briaux, A.; Cabou, C.; Garcia, C.; Lairez, O.; Foidart, J.M.; et al. Effect of estetrol, a selective nuclear estrogen receptor modulator, in mouse models of arterial and venous thrombosis. Mol. Cell. Endocrinol. 2018, 477, 132-139. [CrossRef]

16. Benoit, T.; Valera, M.C.; Fontaine, C.; Buscato, M.; Lenfant, F.; Raymond-Letron, I.; Tremollieres, F.; Soulie, M.; Foidart, J.M.; Game, X.; et al. Estetrol, a Fetal Selective Estrogen Receptor Modulator, Acts on the Vagina of Mice through Nuclear Estrogen Receptor $\alpha$ Activation. Am. J. Pathol. 2017, 187, 2499-2507. [CrossRef]

17. Foidart, J.M.; Gaspard, U.; Pequeux, C.; Jost, M.; Gordenne, V.; Tskitishvili, E.; Gallez, A.; Valera, M.C.; Gourdy, P.; Fontaine, C.; et al. Unique Vascular Benefits of Estetrol, a Native Fetal Estrogen with Specific Actions in Tissues (NEST). In Sex Steroids' Effects on Brain, Heart and Vessels; Springer: Cham, Switzerland, 2019; pp. 169-195. [CrossRef]

18. Coelingh Bennink, H.J.T.; Heegaard, A.M.; Visser, M.; Holinka, C.F.; Christiansen, C. Oral bioavailability and bone-sparing effects of estetrol in an osteoporosis model. Climacteric 2008, 11, 2-14. [CrossRef] [PubMed]

19. Pluchino, N.; Drakopoulos, P.; Casarosa, E.; Freschi, L.; Petignat, P.; Yaron, M.; Genazzani, A.R. Effect of estetrol on beta-endorphin level in female rats. Steroids 2015, 95, 104-110. [CrossRef] [PubMed]

20. Pluchino, N.; Santoro, A.N.; Casarosa, E.; Giannini, A.; Genazzani, A.; Russo, M.; Russo, N.; Petignat, P.; Genazzani, A.R. Effect of estetrol administration on brain and serum allopregnanolone in intact and ovariectomized rats. J. Steroid Biochem. Mol. Biol. 2014, 143, 285-290. [CrossRef]

21. Giretti, M.S.M.S.; Montt Guevara, M.M.; Cecchi, E.; Mannella, P.; Palla, G.; Spina, S.; Bernacchi, G.; Di Bello, S.; Genazzani, A.R.; Genazzani, A.D.; et al. Effects of Estetrol on Migration and Invasion in T47-D Breast Cancer Cells through the Actin Cytoskeleton. Front. Endocrinol. 2014, 5, 1-9. [CrossRef]

22. Gérard, C.; Blacher, S.; Communal, L.; Courtin, A.; Tskitishvili, E.; Mestdagt, M.; Munaut, C.; Noel, A.; Gompel, A.; Péqueux, C.; et al. Estetrol is a weak estrogen antagonizing estradiol-dependent mammary gland proliferation. J. Endocrinol. 2014, 224, 85-95. [CrossRef] [PubMed]

23. Singer, C.F.; Bennink, H.J.T.C.; Natter, C.; Steurer, S.; Rudas, M.; Moinfar, F.; Appels, N.; Visser, M.; Kubista, E. Antiestrogenic effects of the fetal estrogen estetrol in women with estrogen-receptor positive early breast cancer. Carcinogenesis 2014, 35, 2447-2451. [CrossRef]

24. Schmidt, M.; Lenhard, H.; Hoenig, A.; Zimmerman, Y.; Krijgh, J.; Jansen, M.; Coelingh Bennink, H.J.T. Tumor suppression, dose-limiting toxicity and wellbeing with the fetal estrogen estetrol in patients with advanced breast cancer. J. Cancer Res. Clin. Oncol. 2021, 147, 1833-1842. [CrossRef] [PubMed] 
25. Gallez, A.; Dias Da Silva, I.; Wuidar, V.; Foidart, J.-M.; Péqueux, C. Estetrol and Mammary Gland: Friends or Foes? J. Mammary Gland Biol. Neoplasia 2021. [CrossRef]

26. Liu, S.; Ruan, X.; Schultz, S.; Neubauer, H.; Fehm, T.; Seeger, H.; Mueck, A.O. Oestetrol stimulates proliferation and oestrogen receptor expression in breast cancer cell lines: Comparison of four oestrogens. Eur. J. Contracept. Reprod. Health Care 2015, 20, 29-35. [CrossRef]

27. Jozan, S.; Kreitmann, B.; Bayard, F. Different effects of oestradiol, oestriol, oestetrol and of oestrone on human breast cancer cells (MCF-7) in long term tissue culture. Acta Endocrinol. 1981, 98, 73-80. [CrossRef] [PubMed]

28. Coelingh Bennink, H.J.T.; Singer, C.; Simoncini, T.; Genazzani, A.R.; Holinka, C.F.; Kubista, E. Estetrol, a pregnancy-specific human steroid, prevents and suppresses mammary tumor growth in a rat model. Climacteric 2008, 11, 29. [CrossRef]

29. Visser, M.; Kloosterboer, H.J.J.; Bennink, H.J.T.C.; Coelingh Bennink, H.J.T.; Kloosterboer, H.J.J. Estetrol prevents and suppresses mammary tumors induced by DMBA in a rat model. Horm. Mol. Biol. Clin. Investig. 2012, 9, 95-103. [CrossRef]

30. Coelingh Bennink, H.J.T.; Skouby, S.; Bouchard, P.; Holinka, C.F. Ovulation inhibition by estetrol in an in vivo model. Contraception 2008, 77, 186-190. [CrossRef]

31. Duijkers, I.J.M.; Klipping, C.; Zimmerman, Y.; Appels, N.; Jost, M.; Maillard, C.; Mawet, M.; Foidart, J.M.; Bennink, H.J.T.C. Inhibition of ovulation by administration of estetrol in combination with drospirenone or levonorgestrel: Results of a phase II dose-finding pilot study. Eur. J. Contracept. Reprod. Health Care 2015, 20, 476-489. [CrossRef]

32. Apter, D.; Zimmerman, Y.; Beekman, L.; Mawet, M.; Maillard, C.; Foidart, J.M.; Coelingh Bennink, H.J.T. Bleeding pattern and cycle control with estetrol-containing combined oral contraceptives: Results from a phase II, randomised, dose-finding study (FIESTA). Contraception 2016, 94, 366-373. [CrossRef] [PubMed]

33. Visser, M.; Coelingh Bennink, H.J.T. Estetrol, the new natural estrogen for clinical use in women. Ref. Gynecol. Obstet. 2011, 14, 427-432.

34. Gemzell-Danielsson, K.; Apter, D.; Zatik, J.; Weyers, S.; Piltonen, T.; Suturina, L.; Apolikhina, I.; Jost, M.; Creinin, M.D.; Foidart, J. Estetrol-Drospirenone combination oral contraceptive: A clinical study of contraceptive efficacy, bleeding pattern, and safety in Europe and Russia. BJOG Int. J. Obstet. Gynaecol. 2021, 1-9. [CrossRef]

35. Creinin, M.D.; Westhoff, C.L.; Bouchard, C.; Chen, M.J.; Jensen, J.T.; Kaunitz, A.M.; Achilles, S.L.; Foidart, J.M.; Archer, D.F. Estetrol-drospirenone combination oral contraceptive: North American phase 3 efficacy and safety results. Contraception 2021, 104, 222-228. [CrossRef]

36. Apter, D.; Zimmerman, Y.; Beekman, L.; Mawet, M.; Maillard, C.; Foidart, J.M.; Coelingh Bennink, H.J.T. Estetrol combined with drospirenone: An oral contraceptive with high acceptability, user satisfaction, well-being and favourable body weight control. Eur. J. Contracept. Reprod. Health Care 2017, 22, 260-267. [CrossRef]

37. Kluft, C.; Zimmerman, Y.; Mawet, M.; Klipping, C.; Duijkers, I.J.M.; Neuteboom, J.; Foidart, J.M.; Bennink, H.C. Reduced hemostatic effects with drospirenone-based oral contraceptives containing estetrol vs. ethinyl estradiol. Contraception 2017, 95, 140-147. [CrossRef]

38. Douxfils, J.; Klipping, C.; Duijkers, I.; Kinet, V.; Mawet, M.; Maillard, C.; Jost, M.; Rosing, J.; Foidart, J.-M. Evaluation of the effect of a new oral contraceptive containing estetrol and drospirenone on hemostasis parameters. Contraception 2020, 102, 396-402. [CrossRef]

39. Mawet, M.; Maillard, C.; Klipping, C.; Zimmerman, Y.; Foidart, J.M.; Bennink, H.J.T.C. Unique effects on hepatic function, lipid metabolism, bone and growth endocrine parameters of estetrol in combined oral contraceptives. Eur. J. Contracept. Reprod. Health Care 2015, 20, 463-475. [CrossRef] [PubMed]

40. Klipping, C.; Duijkers, I.; Mawet, M.; Maillard, C.; Bastidas, A.; Jost, M.; Foidart, J.M. Endocrine and metabolic effects of an oral contraceptive containing estetrol and drospirenone. Contraception 2021, 103, 213-221. [CrossRef]

41. Stegeman, B.H.; de Bastos, M.; Rosendaal, F.R.; van Hylckama Vlieg, A.; Helmerhorst, F.M.; Stijnen, T.; Dekkers, O.M. Different combined oral contraceptives and the risk of venous thrombosis: Systematic review and network meta-analysis. BMJ 2013, 347, f5298. [CrossRef] [PubMed]

42. Farris, M.; Bastianelli, C.; Rosato, E.; Brosens, I.; Benagiano, G. Pharmacodynamics of combined estrogen-progestin oral contraceptives: 2. effects on hemostasis. Expert Rev. Clin. Pharmacol. 2017, 10, 1129-1144. [CrossRef]

43. Montt-Guevara, M.M.; Palla, G.; Spina, S.; Bernacchi, G.; Cecchi, E.; Campelo, A.E.; Shortrede, J.E.; Canu, A.; Simoncini, T. Regulatory effects of estetrol on the endothelial plasminogen pathway and endothelial cell migration. Maturitas 2017, 99, 1-9. [CrossRef] [PubMed]

44. Rahman, M.S.; Woollard, K. Atherosclerosis. Adv. Exp. Med. Biol. 2017, 1003, 121-144. [PubMed]

45. Arnal, J.-F.; Scarabin, P.-Y.; Trémollières, F.; Laurell, H.; Gourdy, P. Estrogens in vascular biology and disease: Where do we stand today? Curr. Opin. Lipidol. 2007, 18, 554-560. [CrossRef] [PubMed]

46. Hodgin, J.B.; Krege, J.H.; Reddick, R.L.; Korach, K.S.; Smithies, O.; Maeda, N. Estrogen receptor $\alpha$ is a major mediator of 17 $\beta$-estradiol's atheroprotective effects on lesion size in Apoe-/- mice. J. Clin. Investig. 2001, 107, 333-340. [CrossRef]

47. Billon-Galés, A.; Fontaine, C.; Douin-Echinard, V.; Delpy, L.; Berges, H.; Calippe, B.; Lenfant, F.; Laurell, H.; Guéry, J.-C.; Gourdy, P.; et al. Endothelial Estrogen Receptor- $\alpha$ Plays a Crucial Role in the Atheroprotective Action of $17 \beta$-Estradiol in Low-Density Lipoprotein Receptor-Deficient Mice. Circulation 2009, 120, 2567-2576. [CrossRef] 
48. Pollow, D.P.; Romero-Aleshire, M.J.; Sanchez, J.N.; Konhilas, J.P.; Brooks, H.L. ANG II-induced hypertension in the VCD mouse model of menopause is prevented by estrogen replacement during perimenopause. Am. J. Physiol. Integr. Comp. Physiol. 2015, 309, R1546-R1552. [CrossRef]

49. Tarhouni, K.; Freidja, M.L.; Guihot, A.L.; Vessieres, E.; Grimaud, L.; Toutain, B.; Lenfant, F.; Arnal, J.F.; Loufrani, L.; Henrion, D. Role of estrogens and age in flow-mediated outward remodeling of rat mesenteric resistance arteries. Am. J. Physiol. Circ. Physiol. 2014, 307, H504-H514. [CrossRef]

50. Darblade, B.; Pendaries, C.; Krust, A.; Dupont, S.; Fouque, M.-J.; Rami, J.; Chambon, P.; Bayard, F.; Arnal, J.-F. Estradiol Alters Nitric Oxide Production in the Mouse Aorta Through the $\alpha-$, but not $\beta$-, Estrogen Receptor. Circ. Res. 2002, 90, 413-419. [CrossRef]

51. Brouchet, L.; Krust, A.; Dupont, S.; Chambon, P.; Bayard, F.; Arnal, J.F. Estradiol Accelerates Reendothelialization in Mouse Carotid Artery Through Estrogen Receptor- $\alpha$ but Not Estrogen Receptor- $\beta$. Circulation 2001, 103, 423-428. [CrossRef]

52. Smirnova, N.F.; Fontaine, C.; Buscato, M.; Lupieri, A.; Vinel, A.; Valera, M.-C.; Guillaume, M.; Malet, N.; Foidart, J.-M.; RaymondLetron, I.; et al. The Activation Function-1 of Estrogen Receptor Alpha Prevents Arterial Neointima Development Through a Direct Effect on Smooth Muscle Cells. Circ. Res. 2015, 117, 770-778. [CrossRef]

53. Guivarc'h, E.; Buscato, M.; Guihot, A.L.; Favre, J.; Vessières, E.; Grimaud, L.; Wakim, J.; Melhem, N.J.; Zahreddine, R.; Adlanmerini, M.; et al. Predominant role of nuclear versus membrane estrogen receptor $\alpha$ in arterial protection: Implications for estrogen receptor $\alpha$ modulation in cardiovascular prevention/safety. J. Am. Heart Assoc. 2018, 7. [CrossRef] [PubMed]

54. Hilgers, R.H.P.; Oparil, S.; Wouters, W.; Coelingh Bennink, H.J.T. Vasorelaxing effects of estetrol in rat arteries. J. Endocrinol. 2012, 215, 97-106. [CrossRef]

55. Montt-Guevara, M.M.; Giretti, M.S.; Russo, E.; Giannini, A.; Mannella, P.; Genazzani, A.D.A.R.; Genazzani, A.D.A.R.; Simoncini, T. Estetrol modulates endothelial nitric oxide synthesis in human endothelial cells. Front. Endocrinol. 2015, 6, 111. [CrossRef] [PubMed]

56. Coelingh Bennink, H.J.T.; Verhoeven, C.; Zimmerman, Y.; Visser, M.; Foidart, J.M.; Gemzell-Danielsson, K. Pharmacokinetics of the fetal estrogen estetrol in a multiple-rising-dose study in postmenopausal women. Climacteric 2017, 20, 285-289. [CrossRef]

57. Raps, M.; Helmerhorst, F.; Fleischer, K.; Thomassen, S.; Rosendaal, F.; Rosing, J.; Ballieux, B.; Van Vliet, H. Sex hormone-binding globulin as a marker for the thrombotic risk of hormonal contraceptives. J. Thromb. Haemost. 2012, 10, 992-997. [CrossRef] [PubMed]

58. Odlind, V.; Milsom, I.; Persson, I.; Victor, A. Can changes in sex hormone binding globulin predict the risk of venous thromboembolism with combined oral contraceptive pills? Acta Obstet. Gynecol. Scand. 2002, 81, 482-490. [CrossRef]

59. Coelingh Bennink, H.J.T.; Verhoeven, C.; Zimmerman, Y.; Visser, M.; Foidart, J.M.; Gemzell-Danielsson, K. Pharmacodynamic effects of the fetal estrogen estetrol in postmenopausal women: Results from a multiple-rising-dose study. Menopause 2017, 24, 677-685. [CrossRef]

60. Gallez, A.; Blacher, S.; Maquoi, E.; Konradowski, E.; Joiret, M.; Primac, I.; Gérard, C.; Taziaux, M.; Houtman, R.; Geris, L.; et al. Estetrol Combined to Progestogen for Menopause or Contraception Indication Is Neutral on Breast Cancer. Cancers 2021, 13, 2486. [CrossRef] 